Bangladesh Journal of Bioethics 2017; 8(3):18-25

\title{
An African Perspective on Surrogacy and the Justification of Motherhood
}

\author{
Akande Michael Aina \\ Department of Philosophy, Lagos State University, Ojo. Lagos, Nigeria. \\ Email: ainaakande@yahoo.com
}

\begin{abstract}
Surrogacy as a practice is supported by science, technology, morality and legality. It follows that the issues concerning it cut across all facets of life. And different arguments have being advanced for and against this practice. The belief espouse in this paper is that one cannot discuss successfully the moral, the science or the legality of surrogacy without delving into the cultural question of who is a mother. In other words, it is possible to have simple scientific and legal understandings of the practice and still disagree on the cultural level because of its stronger emotional appeal. The purpose of this work is to expose the Yoruba-African religio-cultural beliefs that have bearing on the understanding of motherhood or ownership of a child. This will be done through a critical analysis of Yoruba cultural beliefs about personhood and the metaphysical underpinning between birth and the ontology of life itself. Theargument here is that given some Yoruba ontological belief about life, motherhood and personhood it may be difficult for the products of surrogacy to fit-in into the society in terms of personal and social development. This work goes further to recommend that cultural beliefs should be taking into consideration when making laws to guide surrogacy in order to avoid conflict between the mothers and the child.
\end{abstract}

Keywords: African belief, Human personality, Ikunle-abiyamo, Motherhood and Surrogacy.

Introduction: In surrogacy arrangement, there are four personalities which are often mentioned in various debates: the mother and father(sperm and egg donours), a woman who is the womb donour, and the child who is the product of the relationship among the adults first mentioned. This is why it becomes imperative to ask who should be the real mother? Though the intention of the couple who hired a surrogate is to have a child of their own yet it is necessary to enquire who best will take care of the child. The relationship among these adults, have consequence to the development and the status of the child and it goes a long way to determine the success and failure of the practice. Certain metaphysical and cosmological principles in Yoruba-African philosophy do help in determining the type of relationship that should exist among all the parties, during and after the arrangement. ${ }^{1}$

It can be a life changing experience for a woman to discover that she cannot give birth to a child in the normal way like other women, but it will be joyous for her to know that she can be assisted through technology to have a child she can call her own. While adoption of children provides certain attractive joy, it is incomparable to having a child with the same genes through Assisted Reproductive Technology (ART). However, this arrangement is not totally free from certain emotional and legal problems for both the child and the couple, who adopt this technology. The concept of ownership can be problematic in surrogacy just as it is in economic and social spheres. In economic circle if something is paid for then the ownership is transferred to the person that paid. In legal terms the ordinary consent to will or transfer anything to another person is enough justification to possess it. Can the same be said in surrogacy arrangement given the emotional attachment among human beings? The cultural dimension to the concept of ownership cannot be ignored in spite of the legal and economic ideas of ownership. 
For this reason, this article will discuss some religio-cultural beliefs among the Yoruba people of Nigeria that have bearing on the decision of ownership of the product of surrogate arrangement. Not minding the legality and the moral consent involved in surrogacy arrangement, these religio-cultural factors can create some problems during the developing years or stages of a child who is birthed through surrogacy. The task in this work is to draw attention to these factors with the aim to help strengthen the laws that will guide surrogacy arrangement in Nigeria and any other culture where such beliefs exist. But before that is done, there is a need do some conceptual clarifications to foster our understanding of the issue. This will be the foundation of the arguments to be projected here.

What is Surrogacy? Etymologically, the term surrogacy is from the Latin word subrogane which means to replace, substitute or stand-in for $^{2}$. It therefore, suggests that there is an original or natural process or thing to be replaced by another process or thing which is not original or natural. In a situation where what is to be substituted is not about naturalness, it can concern what is legitimate being replaced by what is not. It is this substitution and its attendant consequences that made surrogacy a moral and legal issue, especially because human beings are involved.

The act of surrogacy involves helping someone to have a child or to meet the need of child bearing. It has being discovered that giving birth to a child is a natural duty of homosapiens and indeed other non-human animals. The duty of procreation to perpetuate young ones in other to populate the world for the continuity of human race is not something that societies and individuals take with levity especially in Africa.
However, as important as it is to procreate, it is a fact that not all human beings have the wherewithal to do so, even when they are willing. Some men are born impotent; some lost it at a stage of life due to sickness, or accident. Also, there are human beings who are fertile in terms of having good eggs and sperms but who have other deficiencies necessary for procreation: ruptured womb, total absence of womb, feeble bodily system or structure, low but active egg sperm count, to mention but a few ${ }^{3}$

Under the above situations, it seems the primary and important factors for procreation are present but the secondary and equally important factors are absent. But the good news is that these secondary factors can be borrowed, bought or negotiated from a willing person, thereby completing the process. What is to be borrowed, bought or negotiated here are another person's body, womb and time while the sperm and the egg belong to original intending parents who are willing to have babies or a baby.

Surrogacy then by interpretation is a form of contract between basically two or three people to carry out a form of biological duty or business. For Odidika Umeora et al (2014) "surrogate motherhood refers to a situation whereby a third party female is commissioned, or elect to carry a pregnancy on behalf of another couple, delivers a baby and hands the child over to the parents at birth"4.

The act by the analysis above takes its name from the surrogate (substituted mother) mother who is the carrier of the embryo and the woman who birthed the child. It therefore, seems that it is only women who are surrogates, but it is possible to have circumstances that could make a man to be a surrogate. 
Types of Surrogacy: The nature of the problem of a couple most of the times determines the type of surrogacy arrangement. Basically there are two types of surrogacy but there are three types of circumstances or conditions for adopting surrogacy. The first type of surrogacy is called traditional surrogacy and the second is called gestational surrogacy.

Two people are involved in the traditional type. The contract is between a woman who is not a wife and a father who donates his sperm to the woman. In this case, the surrogate mother is equally the biological mother since her egg is the one being fertilized through Intrauterine Insemination (IUI). This process is at times called partial surrogacy. In gestational surrogacy, three people are involved. In this process, the embryo is created first by fertilizing the egg of the commissioning mother with the sperm of the commissioning father through vitro-fertilization before transferring the embryo to the surrogate mother's womb. In this process, the surrogate mother is not genetically linked to the child. It can also be referred to as full surrogacy ${ }^{6}$. In both types of surrogacy, there are moral, legal, economic, psychological, religious and socio-cultural implications. While some surrogacy arrangements are purely altruistic depending on the relationship already established between the surrogate mother and the commissioning couple, others are egoistic. Some surrogate mothers consented to carry the fetus for self-financing, and some commissioning mothers run from the pains of birth and motherhood; both circumstances are egoistic in these respects. Whereas surrogate mothers that agreed based on friendship and family relationship and commissioning fathers who donate their sperm for free so that someone might enjoy the taste of motherhood are altruistic in that respect.
One reason for engaging in surrogacy is the dictates of modern societies where some jobs dictate to women when not to be pregnant, this can make them transfer the duty of given birth to another woman. It has also being observed that some women want to avoid the pain of carrying a pregnancy for 9 months and the attendant painful process of birth. The third reason is the health and biological conditions of the intending couple.

Surrogacy is therefore multifaceted in terms of the reasons adduced for its practice and the benefits that can accrue from it. The purpose of this work is to explore the religio-cultural dimension especially as it relates to certain metaphysical beliefs of the Yoruba people which may discourage the practice or affect the status of the child in that society. It is for this purpose that we shall turn to Yoruba cultural beliefs about motherhood and human personality.

Yoruba Idea of Human Personality and the View about Life: The Yoruba people are majorly from the Western part of Nigeria, which is the most populous country in Africa. Nigeria comprises of about three major ethnic nationalities: Yoruba, Igbo and Hausa with sub-ethnic groups numbering about two hundred and fifty tribes. Outside Nigeria the Yoruba people are found in Brazil, Cuba, America and some West African countries like Republic of Benin and Togo ${ }^{7}$. A recent study estimates the population of the Yoruba people quite a bit over 25 million ${ }^{8}$.

In Yoruba ontology, spirit is the life force which controls the lives of every occupant of the physical world. This belief does not exclude the belief in material life force but it places the spiritual in a vantage position. God, divinities, ancestors, men, animals and plants share in these mythical forces. While God is at the apex of life, the plants are at the base. Even non-living things like stones occasionally are possessed by spirits ${ }^{9}$. 
Inspite of the differences between spirit and matter, Yoruba people believe that there is a harmonious relationship between them. This explains Chiedozie Okoro assertion that African philosophical metaphysics espouse a duality of being rather than dualism ${ }^{10}$. All these qualifications are attempts to show the interdependency of the material and the spiritual.This philosophy permeates other traditional thoughts especially those of destiny, personhood, which are the focus of this section.

Components of Human Personality: In traditional Yoruba thought, a person is made up of both spiritual and physical parts. The physical part consists of ara (body), ese (leg), and okan(heart) while the spiritual part has emi (soul), ori (inner head), okan (heart) and ese (inner leg). ${ }^{11}$ Though, it may be enough to mention ara, ori and emi as the major components but the Yoruba philosophy having found some functions for ese and okan in the development and realization of individual destiny, Balogun decided to include them in addition to the main ones.

Notwithstanding the special function that is unique to each of these components their connections cannot be ignored. For example, ara, carries both the ori and the ese while emi is connected to the ara as the engine house, it is also connected to okan which is the physical representation of the mind. Ori and Ese and are connected as spiritual components.

Ara (body) is the physical part of the human person which is responsible for movement and other physical activities. But it is essentially the house of emi (soul) which is responsible for life. Without emi, ara is useless especially as it relates to life and bodily movement. Ori (inner head) is the carrier of human destiny in conjunction with ese (inner leg). The uniqueness of Yoruba traditional thought about human personality is that these components have both spiritual and physical manifestation. Every individual in this regard is both a physical and a spiritual being.

It is for the above reason that Okoro Chiedozie describes African metaphysics of existence as a duality, rather than a dualism. While dualism is the belief in two separate entities, duality is the belief in two distinct but inseparable entities. However, from the foregoing, the belief in human personality can be categorized as tripartite conception because it consists of the natural (ara), the supernatural/psychic(okan, ese) and the spiritual (emi).Ese and okan are categorized as supernatural here because they have both natural and spiritual manifestations ${ }^{12}$. Whatever anyone is or will become can only be explained by both physical and spiritual factors.

The idea of destiny in Yoruba thought just like that of human personality mirrored a tripartite approach. There is Akunleyan (that which one kneeled down to choose), Akunlegba (that which is bestowed on one while kneeling down) and Adayeba (which is the destiny (opportunities) of one's immediate environment in the world). So, what a person will become depends on these three sorts of destiny ${ }^{13}$. Akunlegba represents the destiny of the body which is not a product of choice. It is what the maker of man or nature embedded in the nature of the physical body. Akunleyan is the choice an individual makes for himself/herself. This is the one that bestowed responsibility on the human person. Adayeba is the social destiny or the opportunities presented by the society. It is this one that connects all choices of different individual who found themselves in the same environment. The destiny(happiness or sadness), opportunities that are shared as a member of a family, organization or society. In other words, the destiny bestowed on a man and the one he chose as a person will only be 
realized if the opportunities in the society are favourable to the others too.

From the above analysis, it can be argued that Yoruba traditional philosophy of life is characterized with interconnectedness of existence. It is for this reasonthat Yoruba people live a communal life and are utilitarian in moral thinking ${ }^{14}$.Living together as a family with the interests of majority taken into consideration in every step of life isat the fulcrum of Yoruba people's social life.

\section{A Yoruba Perspective on the Status of a Child in Surrogate Arrangement: The robustness of debates on surrogacy is not in doubt.Nevertheless, Nigeria which housesthe largest population of the Yoruba has not taken a stand on any of the above consideration. As a matter of fact, the issues in surrogacy have not been placed in the centre of any discussion on motherhood and the birth process, though the practice exists.}

This work therefore,centered its focus on the religio-cultural or metaphysical implications of surrogacy which is hardly discussed in previous debates either in the West or in Africa. The first belief to be considered that borders on the argument about ownership is the belief that blood is sacred. No wonder the saying: 'blood is thicker than water' is used to express the bond between family members. The question of ownership is necessary because of the great importance placed on blood in Yoruba traditional thought. To an average Yoruba person, the life of an animal or person is in the blood. In accordance to this belief, the woman that smearedher blood on the child at birth is the right owner of the child. This concept is called ikunle abiyamo (the pain of motherhood or the authority of motherhood).Mothers in Yoruba culture always invoke this authority of motherhood to make demand or pray for their children. ${ }^{15}$
If a woman says emi ni mo da eje si lori (I am the one that pour blood on him/her) she is making a claim of ownership and therefore authority of parenthood is morally and spiritually conferred. Another saying of note here is inu mi ni mo fi bi e meaning I bore you from my womb. The authority of the smeared blood and womb invigorate the philosophy of duality of existence subscribed to by the Yoruba people. In this wise, the internal and the external factors of procreation is only complete in the surrogate mother rather than the commissioning mother. While the womb represents the physical body, the blood represents the spiritual content of reproductive process. The argument here differs from the Western paradigm where the egg and sperm which are physical without the internal spiritual content impose ownership of the child on the commissioning mother.

Nevertheless, the legality of a contract signed between the surrogate and the commissioning couple is not in doubt, and it must be added that Yoruba tradition places emphasis on the honouring of an agreement between two people. Yet, when the chips are down, when the child has any spiritual problem that warrant solution through the mother, the surrogate mother will be the first point of call.

This leads us to the second issue which is the belief about oro idile (family tradition or taboo). In every traditional Yoruba families, there are cultural rites peculiar to each. These rites or family traditions are performed at various stages of development of a person: from birth, during naming ceremony, during marriage ceremony and finally at death. These rites have deep spiritual meaning in terms of protecting a person from evil. In most cases, they have their foundation in ancestral covenant which are sealed with family blood. In surrogacy, it then becomes difficult to know the effectiveness of these rites in a person who only belong to a family partially. Since a product of surrogate arrangement has no 
blood relation with the surrogate mother but has relation in terms of being the one that smeared blood on the child. So, which ancestral covenant will take eminence in surrogacy is difficult to determine.

It is not surprising given the factor interconnected existence that in consulting an oracle about a child's destiny, the soothsayer (Babalawo) always asks for the name of the child and the child's mother. This is predicated on the belief that one cannot be mistaken about who a child's mother is, because the paternity of a child is uncertain except determined through DNA. There is therefore, a great affinity between a person's destiny and that of the mother ${ }^{16}$. It then becomes difficult to know which mother's name will be presented since in surrogacy two mothers are involved. But we feel that the authority of the womb and the smearing of blood may also be applicable here.

Ifa oracle which is the religious book of the Yoruba people also mentioned that "a child who fails to suck the mother's breast milk, will find it extremely difficult, if not totally impossible, to have the type of spiritual elevations comparable to those of hi/her colleague who had the benefit of sucking their mother's breast milk ${ }^{17}$. If a child lost the mother at birth $s /$ he has lost the privilege of breast sucking. Such situation may also occur if a mother is HIV positive or having any other disease that can be transferred through body fluid. Surrogacy itself presents such situation if the baby is transferred immediately to the commissioning couple after birth. Though, the Western science takes the DNA and genes as the determinant of personality, the Yoruba people do not dwell on this physical attributes alone, the spiritual dimension of birth and growing processes are of utmost importance or else one ceases to be a 'normal' or 'full person'. And this is where surrogacy becomes a problem in Yoruba philosophy. In the Shakespearean novel titled Macbeth,
Macbeth who is the hero in this play boasts to Macduff that he cannot be killed by Macduff because the gods already told him that Macbeth cannot be killed by any man born of a woman. Macduff replied him that technically he was not born (of a woman) in the natural way but was given birth to through a cesarean operation ${ }^{18}$. This made all the three factors that could lead to the death of Macbeth complete. Macbeth dies in the battle between him and Macduff. It shows that some of the metaphysical beliefs about birth, motherhood and life in general have serious implications for the status of the surrogate mother and the child who is a result of surrogate arrangement. This is in line with Mary Douglas's assertion that the "understanding of religious symbols helps in selecting experiences for concentrated attention". For her, this will further help in the mysterious coordination of brain and body. ${ }^{19}$

Conclusion: The strength of the link developed through gestation and birth seems stronger than that of genetic link between the fetus and the commissioning parents. Yoruba seems to realize that carrying an embryo and giving birth give stronger emotional and spiritual ties from the surrogate mother to the child than the one developed through genetic means by the non-pregnant commissioning biologic-mother. According to Nancy Reame(1991:153), ACOG (American College of Obstetricians and Gynecologists) in 1983 set up a committee on Ethics and part of the recommendations that lend credence to the Yoruba position is that the surrogate mother should be treated as the natural mother ${ }^{20}$. The committee however arrived at this due to the fact that surrogate mothers deserve autonomy on their bodies, health and the need to prevent negative psychological health risk

Various researches (Kennel \&McGrath, 2002 and Palmer, 2002)21, 22have also corroborated that biological bonds are established between 
mothers and her fetuses during pregnancy through the following means:
a. Oxytocin homone
b. Skin-to-skin contact
c. Eye gazing
d. Breast feeding

All these socio-cultural beliefs and scientific facts show thatthere is a form of bonding between mothers and children and these factors are complete only in the surrogate mother. And one ought to be concerned about the disruption of this boding which surrogacy attempt to cause by acknowledging the commissioning parents over and above the surrogate parent. The belief in this paper is that such acknowledgement will create a kind of genealogical bewilderment,that is, a confused family structure for the child which may affect the child's development.

So, the question: Is parenthood grounded in biology, contractual agreement or religiocultural arrangement, will be better addressed if the answer considered both the biologic and religio-cultural factors concerned. These factors in the thinking of this work are complete in surrogate motherhood. It is not then out of place to recommend that any legal or moral framework must be seen to maintain good relationship between the surrogate mother and the commissioning couple in order to respect the dignity and welfare of the child which enhances physical development, and to avoid spiritual underdevelopment of the child.

Ifthere is no such good relationship between the parties, and economic consideration is the reason for agreeing to be a surrogate mother, it could lead to extortion when situation arises in future; where the help of the surrogate mother is needed as it affects the child's destiny and development in life. Any legal framework of agreement should envisage this and take care of it.

\section{Conflict of interest: None}

Acknowledgement: I thank Rainer Ebert for the information he placed on Facebook about this edition. Grateful heart!

\section{References}

1 Douglass, M.Purity and Danger. London: Penguin, 1966, P.63

2 Umeora, Odidika et al. "Surrogacy in Nigeria: Legal, Ethical, Sociocultural, Psychological and Religious Musings" in African Journal of Medical and Health Sciences.2014. Vol. 13 no. 2 retrieved at http://www.ajms.org

3 Llewellyn-Jones, D. Everywoman: $A$ Gynecological Guide for Life. Ibadan: Safari Books. 1998. P.89-91.

$4 \quad$ Umeora Odidika et al op. cit

5 Coste B. "The Ethics of Surrogacy: A list of the Pros and Cons of Surrogacy" retrieved at http://www.positive-parenting-ally.com

6 Coste, B. ibid.

7 Oduwobi, T. \& Obi, I. "Nigeria: An Ethnic Historical Survey" in Akinjide and Olukoju (eds.) Nigerian Peoples and Culture. Ibadan: Davidson Press. 1997

8 Jemiriye, F. "Yoruba Understanding of Sexuality" 2015, retrieved at http://tfjemiriye.org

9 Dukor, M. Theistic Humanism of African Philosophy..Saarbrucken: Lap Lambert. (2010).

10 Okoro, C. "The Notion of Integrative Metaphysics and its Relevance to Contemporary World order" in Integrative Humanism Journal,2011.vol. 2 no. 2: pp. 3-28.

11 Balogun $O$. "Ori as the sole Determinant of Human Destiny in Traditional Yoruba-African Thought" in Lumina, 2010 Vol. 21, no. 2.P.1-9. 
12 Gbadegesin, S. African Philosophy, Traditional Yoruba Philosophy and Contemporary African Realities. Chicago: Gateway. 1991, P. 28.

13 Oladipo, O. "Predestination in Yoruba Thought: A Philosopher's Interpretation" in Orita: Ibadan Journal of Religious Studies. 1992 Vol. XXIV, No. 1\&2, P.43.

14 Oluwole, S. "The Rational Basis of Yoruba Ethical Thinking" in The Nigerian Journal of Philosophy 1984 vol. 4 no. $1 \& 2$.

15 Popoola, S. and Oyesanya, F. Ikunle Abiyamo: The Ase of Motherhood. Ibadan: Ifa Works. 2015.

16 Awala, V. "10 Fascinating Superstitious Beliefs Common with Yoruba People" retrieved at http://www.informationng.com

17 Popoola and Oyesanya, op. cit. P.172.

18 Shakespeare W. Macbeth. Act 5, scene 1-11

19 Douglass M. Op. Cit. P.63.

20 Reame, N. "The Surrogate Mother as a High-Risk Obstetric Patient" in the journal of The Jacobs Institute of Women's Health.1991, Vol.1 no. 3 Summer.

21 Kennell J. and MCGrath S. "Starting the Process of Mother-infant Bonding" in Acta Paediatrica, 2002, Vol. 94 no. 6.

22 Palmer, L. "Bonding Matters: The Chemistry of Attachment" in Attachment Parenting International News, 2002. vol. 5 no. 2 retrieved at http://www.babyreference.com 